\title{
The Transition from Myth to Art from a Losevian Perspective: An Analysis of the Culladhanuggaha Jätaka as Myth and Its Transition into Sri Lankan Folk and Classical Theatre
}

\author{
Nandaka Maduranga Kalugampitiya \\ Ohio University, USA
}

\begin{abstract}
Based on an analysis of the Culladhanuggaha Jätaka and its Sri Lankan theatrical adaptations (the Manamé Kōlama and Ediriweera Sarachchandra's play Manamé Nätakaya), the paper explores the relationship between myth and art. It uses Aleksei Fyodorovich Losev's theory of myth as the framework for the analysis of the Culladhanuggaha Jattaka as myth and the changes that the story undergoes when it enters the realm of art. The paper argues that while the transference of the story from myth to art strips the story of much of its mythical character, the story even in its new context remains tied to the notion of myth in an important manner. The paper concludes with the argument that the theatrical pieces in question embody a broader consciousness defined by both the mythical consciousness and the poetic consciousness in the Losevian sense of the terms.
\end{abstract}

Keywords:myth, art, theatre, Aleksei Fyodorovich Losev, mythosophy, jataka, Maname, kolam

\section{Introduction}

The union between myth and art could be seen as fundamental to human expression. Numerous cases that exemplify this union can be found from cultures across the globe. The paper explores the relationship between myth and art, specifically theatre, from the perspective of Aleksei Fyodorovich Losev's conception of myth. It investigates the transformation that a myth undergoes when it is transferred from the realm of ritual to the realm of art. Through an analysis of the Buddhist Jataka story Culladhanuggaha Jātaka, the three hundred and sixty eighth story in the Pansiya Panas Jätaka Poth Wahanse [The Revered Book of Five Hundred and Fifty Jātaka Stories]; ${ }^{1}$ Manamé Kōlama, ${ }^{2}$ which is a Sri Lankan Sinhala folk

${ }^{1}$ The Pansiya Panas Jätaka Poth Wahanse [The Revered Book of Five Hundred and Fifty Jātaka Stories] is a collection of stories about the Lord Buddha's previous births. 
theatre adaptation of The Culladhanuggaha Jātaka; and Professor Ediriweera Sarachchandra's play Manamé Nätakaya(1956), ${ }^{3}$ which is based on the same jātaka story and which marked a turning point in the Sinhala theatrical tradition, the paper argues that the transference of the Culladhanuggaha Jātaka from the realm of myth to the realm of art gives rise to a space that is defined by a complex interrelationship between myth and art but can be reduced to neither of the alternatives.

\section{The Culladhanuggaha Jātaka}

The Culladhanuggaha Jātaka is centred around a life experience of the daughter of the Disapamok ${ }^{4}$ of the city called Thakksilā in Gandhāra, a kingdom in ancient India. The Disāpāmok gives her in marriage to his best student who excels in his studies, especially in archery. In recognition of his excellence in archery, the Disāpāmok also bestows the appellation dhanuddhara ('the Master of Archery') on him. After the completion of his studies, he leaves for his hometown Benāres with his newly wedded wife (who will hereafter be referred to as princess). On their way, they see a group of robbers and the Brahmin prince sends the princess to the robbers to ask for some food. The robbers offer her some raw meat. When the prince sees that the robbers have offered them raw instead of cooked meat, he gets into an argument with the chief of the robbers, and this argument culminates in a physical confrontation between the two. The prince subjugates the leader of the robbers and asks his wife for the sword to behead him. The princess, instead of complying with her husband's request, gives the sword to the leader of the robbers who in turn kills the prince. The leader of the robbers understands that he got his life back because the princess betrayed her husband and caused his death. Realising that she may treat him in the same way if he gave her refuge, he robs her of her jewellery and abandons her in the jungle.

Having witnessed this incident in the human world, Sakka (or Śakra), the ruler of the gods, decides to teach the princess who

\footnotetext{
2 While there are a number of versions of the Manamé Kölama, which are slightly different from each other, the version that the present paper examines is the one published in the following text: Manamé Kōlama [The Manamé Kōlama], Ed. Tissa Kariyawasam (Kelaniya: Sheela Printing Works, 1986).

${ }^{3}$ Ediriweera Sarachchandra, Manamé (Colombo: S. Godagé and Brothers, 1958).

${ }^{4}$ Disāpämok was the master teacher under whom all the key Brahmins and royal princes pursued their educational goals in their respective fields. The word Disāpämok can be translated into English as a teacher who is universally knowledgeable.
} 
became a victim of her own action a lesson. He summons Pañcasikha (his Gāndharva or musician) and Mātali (his charioteer) and asks one to assume the appearance of a hawk and the other of a fish. Sakka himself takes the appearance of a jackal. Having given Pañcasikha and Mātali instructions as to what they should do, Sakka enters the human world. The jackal takes a piece of meat in his mouth and appears in front of the princess. At this point, he sees a fish leaping up from the nearby stream and falling onto the bank. When he sees the fish he drops the piece of meat that he carried in his mouth and tries to grab the fish, but the fish escapes back into the stream. In the meantime, the hawk seizes the piece of meat and flies up into the air. Having seen what happened to the jackal, the princess laughs heartily. Then Sakka explains to the princess that she, who has lost both her husband and the man for whom she sacrificed him, is no better than the jackal she is laughing at. When the princess realises what she has done, Sakka gives her advice about the importance of being loyal to one's spouse and leaves the human world accompanied by Pañcasikha and Mātali.

\section{The Culladhanuggaha Jätaka as Myth from a Losevian Perspective}

The story in the Culladhanuggaha Jātaka consists of two distinct yet interrelated parts. The first part represents the "ordinary" realm of existence in the sense that it involves "ordinary" human beings who occupy "ordinary" roles, such as a woman, a man, a person of knowledge, a teacher, a parent, a Brahmin, a student, an archer, a lover, a robber, and a ruler, and "ordinary" occurrences, such as a teacher imparting knowledge to a students, a student pursuing education under the supervision of a teacher, a father giving his daughter away in marriage, a woman and a man getting married, a married couple travelling from one place to another, two men getting into an argument, fighting each other, one getting killed in the fight, and one person being abandoned by another. The second part of the story is different from the first part in the sense that many of the individuals and occurrences that the second part involves are "extraordinary" in character. These "extraordinary" characters are the ruler of the gods, his musician and charioteer, and a jackal that comprehends and speaks the human tongue. The "extraordinary" occurrences that it involves certain characters travelling between heaven and earth, taking on appearances that are completely different from their original forms, and then returning to those original forms. 
These two distinct yet interrelated parts of the story reflect two planes of existence-the "ordinary" and the "extraordinary" - that converge in the culminating moment of the story. It is such convergence that Losev recognizes as miraculous (152). The fact that he equates the notion of myth with the notion of miracle in his final definition of myth indicates the role that miracle plays in his conception of myth. ${ }^{5}$ Losev discusses the notion of miracle from a profoundly philosophical point of view. He views a miracle as a personalistic reality that is characterised by the interaction of two planes of personhood: the historical plane and the plane of internal design (153). He defines the plane of the internal design of a person as "the person by herself, apart from her change and her history, i.e., the person as an idea, principle, the meaning of her entire becoming, and the immutable rule by which her actual becoming aligns itself" (155, emphasis in original) and the historical plane as "the history of that person, her actual flux and alogical becoming, continuous and uninterrupted, fluid multiplicity-unity, her utter fluid homogeneity and purely temporal duration and tension" (155, emphasis in original). According to this conception of miracle, each and every moment of one's existence is inherently miraculous and, therefore, mythical. From a Losevian perspective, one could even argue that miracle is the domain of what provides the condition of possibility for every being to $b e$. The miraculous nature of the interaction of the two planes of being is thus fundamental to all existence that its manifestations are generally perceived to be natural. The realities that are perceived as miracles, one could argue from a Losevian perspective, are the instances where the interaction between the two levels of personhood takes a form larger than that of the miracles that characterise every moment of existence. The examples of transmogrification found in the Culladhanuggaha Jätaka could be seen as such instances where the interaction between the plane of

\footnotetext{
${ }^{5}$ Combining, in a comprehensive definition, his extensive argument that myth is personalistic being, historical being, and a word, Losev argues, "'Person', 'history', and 'word'-this series of concepts has made it necessary for us to create a category that would embrace both the whole series at once and the 'supernatural' or the 'extraordinary'-within a single indivisible point, so that this last nonmaterial, non-metaphysical, and non-poetical, but purely mythical detachment would be joined in a single synthesis with the manifested nature of myth, with the symbol, with the self-consciousness of a person, with a historical event, and with the word as the origin of the source of self-consciousness itself. This means that we have arrived at the concept of miracle. Myth is miracle. This is the longawaited and now the final formula that synthetically embraces all of the antinomies and antitheses considered above" (144-145, emphasis in original).
} 
internal design and the historical plane takes a form that looks strange in comparison to the form of those regular miracles whose miracle status is unmarked. The story includes three charactersSakka, Pañcasikha, and Mātali-who, while remaining essentially themselves, take different forms. The fact that the "original" beings are from the divine realm, while the acquired forms necessarily belong to the temporal realm, emphasises the miraculous nature of this transmogrification. At the same time, the fact that the acquired forms represent beings that are considered to be inferior to human beings but that speak human tongue further emphasizes the miraculous nature of the event. The interaction between the divine beings disguised as subhuman beings and the princess in the story points to another dimension of the miraculous event in question.

The Culladhanuggaha Jātaka ends with a sense of harmonious resolution, and this resolution underlines Ernst Cassirer's claim, "Myth...strives for a 'unity of the world' and in this striving moves in very specific channels prescribed by its spiritual nature" (62). Myth imposes some form of order on the universe that is fundamentally chaotic. Pointers to a certain level of this fundamentally chaotic nature of the universe could be found in the first part of the story. A Brahmin prince pursuing his studies under the supervision of one of the most distinguished teachers at the time, the teacher giving his daughter to the Brahmin prince in marriage, the prince sending his newlywed wife to the robbers in search of food, the confrontation between the prince and the chief of the robbers, the princess betraying her husband in this confrontation, thereby causing his death, and the princess later being abandoned by the chief of the robbers and finding herself in a desperate situation-all these events point to the chaotic nature of the universe. ${ }^{6}$ The events that culminate in the death of the prince indicate the fallibility, unpredictability, and vulnerability of the human being. Hopelessness emerges as a fundamental trait of the universe that these events constitute. The universe that had reached the height of chaos at the end of the first half of the story begins to move towards a harmonious unity in the second half of the story, and this change is initiated by a mythical synthesis of two levels of existence. This synthesis leads the way to a structuring of the chaotic universe. The story ends with a universe that is defined by a strong

\footnotetext{
${ }^{6}$ While some of these events, if not all of them, have the appearance of being indicators of a structured level of existence at one level or another, the paper argues that they all are representations of a chaotic universe in comparison to the 'structuredness' of the universe found at the end of the story.
} 
sense of completion and fulfilment. The realisation the theatrical performance presented by the three divine beings brings about in the princess conveys this impression of a complete and fulfilled universe. It marks the conclusion not only of the Culladhanuggaha Jätaka, but also of the old world order that the first half of the story represented.

Reading the Culladhanuggaha Jātaka from a Losevian point of view, one could argue that it creates a universe of its own, which the mythical consciousness is comfortable with. ${ }^{7}$ Although a universe in which supernatural beings intervene in earthly events with the aim of changing their course would be nothing but pure fantasy to a non-mythical subject, to a mythical subject it is nothing less than reality. In the world of a mythical subject, beings like Sakka, Pañcasikha, and Mātali are rational beings and their intervention in the human world a rational act. The type of intervention of supernatural beings that the Culladhanuggaha Jätaka describes would not appear impossible to the mythical subject. She would recognise the strangeness of the intervention, but she would not doubt its possibility. ${ }^{8}$ For her, the sense of completeness and structuredness that this intervention introduces generates reality. This reality exists in concrete terms and there is nothing abstract about it. To the mythical subject, Sakka, Pañcasikha, and Mātali in the story in question are no less real than the human and animal characters in the story. The only characteristic that separates them from the other characters is that they belong to the divine realm. It is in this sense that what the story presents forms what Losev calls a tangible, sensuous, and authentic reality.

\section{From the Culladhanuggaha Jātaka to the Manamé Kōlama and Manamé Nãtakaya}

The Manamé Kōlama and the play Manamé Nātakaya could be seen as instances where the story of the Culladhanuggaha Jätaka leaves

\footnotetext{
${ }^{7}$ Losev emphasises the need to look at myth from the point of view of the mythical consciousness itself. From that point of view, according to Losev, myth is "a reality that is vitally experienced and created, material and corporeal - corporeal to the point of animal-like palpability" (12, emphases in original), "a living subject-object interaction containing its own extrascientific, purely mythical veracity and authenticity, as well as fundamental regularity and structure" (27, emphases in original), and an "actually, tangibly, and sensuously created reality...detached from the ordinary course of things" (33, emphases in original).

${ }^{8}$ Losev argues, "The fantastic, unprecedented, and extraordinary nature of events is given in it [i.e., myth] as something simple, manifest, immediate, and even openly naïve. It occurs in myth as if it were something usual and customary" (59).
} 
the realm of myth and enters the realm of art. As the story is no longer part of the mythical realm, the mythical consciousness loses its status as the primary framework within which the story should be understood. Considering that the Culladhanuggaha Jãtaka like any other myth runs the risk of being reduced to the level of mere fantasy when approached from a perspective other than mythical, one would naturally expect this shift from the mythical realm to the artistic realm to transform the manner in which the story in question is perceived and treated.

Losev's conception of the distinction between myth and poetry provides important insights into the kind of change that the original story undergoes due to this shift. According to Losev, there are certain marked similarities between myth and poetry, and, by extension, art in general. He identifies four characteristics that they have in common. The first similarity concerns the nature of the mythical and poetic images. According to Losev, "mythical and poetic images both represent types of expressive form in general" (55, emphasis in original). These images are defined by a "synthesis of the 'internal' and 'external', the power that forces the 'internal' to manifest itself and the 'external' to draw into the depth of the 'internal'" (55, emphasis in original). This similarity should be understood in the light of his arguments that a word is a symbol that embodies a synthesis of the internal and external ${ }^{9}$ and that both myth and poetry are primarily verbal $(55$, emphasis in original). The second similarity concerns the level of intelligence that defines the mythical and poetic expressions. Losev argues, "mythology and poetry are intelligence in the same degree, i.e. they are not only expression but animated, spiritualized expression (56, emphasis in original). Losev's discussion of myth as "personalistic being" (134-135) and his claim that poetry is "life seen from within" (56, emphasis in original) explain the basis for this similarity. The third similarity involves the mythical being and poetic being. Losev argues, "both poetic being and mythical being are immediate and non-derivative" (57, emphasis in original). He further argues, "An image in poetry or mythology needs no logical system, science,

\footnotetext{
${ }^{9}$ Losev's conception of 'word' as a symbol defined by a synthesis of the internal and external becomes clear in the following section: "What is, however, a creatively given and actively expressed self-consciousness? It is a word. In language, consciousness becomes self-consciousness. Meaning is expressed in a word as the organ of self-consciousness and, consequently, of opposing oneself to everything else. A word is not only nature understood by someone but also nature that has understood itself, i.e., understood and understanding nature" $(142$, emphasis in original).
} 
philosophy, or theory. It is vividly and immediately seen. Expression is given here in living visages and faces; to understand, one needs only to look and see" (57). The fourth and final similarity concerns the notion of detachment (57). He argues that myth and poetry embody what he calls a mythical detachment and a poetic detachment respectively.

Although Losev views detachment as a characteristic common to myth and poetry, he argues that mythical detachment and poetic detachment 10 are of two fundamentally distinct types. He recognises detachment as the realm in which the distinction between myth and poetry is most obvious. ${ }^{11}$ Defining what he means by poetic detachment, Losev states, "As art in general, poetry has the character of detachment in the sense that it arouses emotions not towards things as such, but towards their definite meaning and configuration" (57). This definition presupposes that what poetry (and art in general) presents is essentially a representation of a reality. The spectator is conscious of the "unrealness" of this representation. This awareness, according to Losev, generates a sense of 'disinterested pleasure' in the mind of the spectator (57). As far as myth is concerned, there is nothing "unreal" about it for the mythical subject. What she is presented with is unmediated reality, not a representation of it. The emotions and feelings that myth arouses in her are anything but disinterested. Mythical detachment, in this sense, is markedly different from the detachment that is typical of art. Losev defines mythical detachment as "detachment from a meaning: from the idea of mundane everyday life" (58). Based on this definition, one couldargue that mythical detachment is a detachment from the everydayness of the meaning of everyday realities. ${ }^{12}$

\footnotetext{
10 The Losevian notion of poetic detachment has its parallels in Immanuel Kant's notion of 'disinterested pleasure' and Bertolt Brecht's notion of 'the alienation effect.' (See Kant and Brecht for a detailed understanding of these notions.) The present paper points to the need for in-depth comparative analyses of these concepts in order to ascertain the exact nature of those parallels.

11 Losev argues, "Finally, a limited similarity can be found in the shared characteristic of detachment. Yet this is precisely the area where mythology and poetry part fundamentally and ultimately, and one needs to be cautious in establishing their similarity" (57).

12 Despite this distinction between poetic detachment and mythical detachment, Losev discusses the important role that poetry/art plays in myth: "Myth, therefore, combines the qualities of both poetic reality and actual material reality. From the former it takes whatever is the most fantastic, fictional, and unreal. From the latter it takes whatever is the most vital, concrete, tangible, and real; it takes all the reality and tension of being, all its elemental factualness and corporeality, all its
} 
The changes that the Culladhanuggaha Jätaka has undergone in the contexts of the Manamé Kōlama ${ }^{13}$ and Manamé Nätakaya ${ }^{14}$ provides important insights into the nature of the transformation that a myth undergoes when it moves from the realm of myth to the realm of art. The Manamé Kölama ${ }^{15}$ features the Brahmin prince and the teacher's daughter as a king and his queen. ${ }^{16}$ When the play begins the king and the queen are already married. The robbers in the source story are replaced with a group of Veddahs, an aboriginal, hunter-gather community, and the chief of the robbers with the chief of that community. The past story about the royal prince who is now a king mastering all arts including archery and receiving the teacher's daughter in marriage and the appellation dhanuddhara in recognition of his excellence in archery is presented in two ways:

non-metaphysical character....It is this synthesis of unexpectedness and naively realistic immediacy that distinguishes mythical detachment from poetic, where there is everything you want, except real things as things" (59).

${ }^{13}$ The Manamé Kölama is one segment in a series of segments presented in a kölam performance. It comes in what Marianne Nürnberger recognizes as the third part of a kōlam performance. Describing kōlam, she writes, "The Sinhalese Kolam performance consists essentially of three parts: the first part contains the prologue or prelude and the enumeration of the characters appearing. It ends with the appearance of the masks of the king and queen. The second part is essentially an unconnected succession ofappearances of masked dancers, who depict figures of diverse origin - human, animal and divine, which are not connected by any particular story. It is only the last part of the performance whichcontains the staging of one or two episodes presented scenically through dance, acting, song and often impromptu dialogues....The conclusion and a kind of an epilogue comes with the appearance of the Gara-Yakkas which is also a component part of many exorcistic rituals. A Kolam season lasts about one week. The night-long scenes all begin with the introductory presentations and end with one or several stories" (114).

${ }^{14}$ Sarath Wijesooriya quotes Sarachchandra where he talks about the play Manamé as representing a new form of theatre based on the theatrical tradition called nädagam (119).

15 Due to the absence of one single accepted text of the Manamé Kölama, the different performances of the Manamé Kōlama by different groups of performers (or even by the same group of performers at different times) could vary from one another. The fact that certain dialogues in the play are performed impromptu indicates the extent to which each performance could vary from the other performances. Despite these variations, all the performances follow the same structure and storyline. The version of Manamé Kölama on which the current analysis is based is the one edited by Tissa Kariyawasam. As mentioned in his Introduction, his version is based on a performance organized by a welfare organization in Rattanapitiya, Boralesgamuwa, Sri Lanka.

16 Although he is introduced as a king at the beginning, in one instance, the Veddah chief refers to him as a young royal prince who is about to become a king. 
first in a short quatrain sung by two moderators/presenters ${ }^{17}$ (who are also singers and drummers) at the very beginning of the performance and second in a conversation between the Veddah chief and his subordinate where the subordinate informs the chief of the royal couple who have entered the scene. The language used in the Manamé Kōlama is present-day colloquial Sinhala, and this contrasts heavily with the classical Sinhala found in the jātaka story. In keeping with the primary aim of a kōlam performance, which is to entertain the spectator, ${ }^{18}$ the Manamé Kōlama includes a number of scenes that use "vulgar" jokes, some of which generate humour using Sinhala words with double meanings and sexual innuendos. Given its religious associations, this kind of humour would be unthinkable in the context of the jätaka story.

Manamé Nātakaya also embodies certain significant deviations from the story of the Culladhanuggaha Jātaka. Like in the Manamé Kölama, the Brahmin prince is presented as a royal prince, and the spectator learns that he is next in line to the kingship of Baranes. Unlike the Manamé Kōlama, Manamé Nātakayaincludes scenes of such events as the teacher conferring the honorary title dhanuddhara on the prince upon the completion of his studies, the marriage between the prince (whose name is Manamé) and the teacher's daughter, and the newlywed couple leaving for Baranes. One of the defining characteristics of the play is its emphasis on romance. The second verse sung by the prince in which he mentions his love for the princess, her dialogue where she tells her father how happy she is to accept the prince as her marriage partner, and the verses sung by the couple and the stylised dialogues exchanged between the two during their journey through the forest create a strong atmosphere of romance. The play, like the Manamé Kōlama, replaces the robbers with a group of Veddahs, but removes the scene where the prince sends his wife to the Veddahs asking for food. The royal couple's entry into the domain of the Veddahs without permission from the Veddah king is shown as the

17 These moderators/presenters introduce the key characters to the spectator before they enter the stage. They also provide the story, which the performance is based on, with a sense of coherence by narrating the sections of the story that are not performed on stage. These narrations are almost always in verse. In addition to introducing the characters and narrating the missing sections, they also provide music to the verses sung by the characters.

${ }^{18}$ Sarachchandra recognises the present tradition of kölam as "a living form of entertainment" (Gunawardena and Sarachchandra 67). M. D. Raghavan argues, "There is perhaps nothing more hilarious and joyous in the whole range of Sinhalese fork arts than the Kolam" (77). 
cause of the conflict. The scene that presents the physical confrontation between the prince and the Veddah king involves highly stylised body movements and lasts a considerable length of time. Unlike in the Manamé Kōlama, the princess does not give the sword to her husband's opponent; the Veddah king snatches it from her. Upon the prince's death, the princess blames the Veddah king for killing her loving husband but agrees to join the Veddah king as his consort, saying that she is in a helpless situation. A genuine romance gradually develops between the princess and the Veddah king. However, this relationship becomes complicated when the princess says that she was impressed at seeing the way the Veddah king fought with bravery and that she even tried to save him by not giving the prince the sword when he had asked for it to behead the Veddah king. In order to establish her point, she goes to the extent of saying that she had even wanted to give the sword to the Veddah king himself. She says that before she could give it to him he snatched it from her. Perplexed by this finding, the Veddah king questions how a woman could perpetrate such a violent crime upon her beloved husband. Saying that he did not want women of such evil nature in marriage, he abandons her in the forest. The play uses a highly stylised poetic language. Like the Manamé Kölama, Manamé Nātakaya also uses a moderator/presenter who introduces the main characters and narrates the events that are important to the narrative but.are not enacted on stage.

The main distinction between the Culladhanuggaha Jätaka and the two theatrical pieces lies in the way they deal with that section of the story, which is inherently mythical. While almost half of the jātaka story is devoted to the episode that involves the merging of the celestial and terrestrial realms, in the Manamé Kölama, this part is limited to a short, relatively little detailed scene. The scene begins with three short quatrains sung by the moderators/presenters, and one of only two references to the divine realm found in the entire scene is given in the first quatrain. This first reference to the divine realm merely states that the Lord Sakka, Pañchasikha (here referred to as 'Mahaviskam'), and Mātali disguised as a jackal, a hawk, and a fish respectively left for the human world. The second and third quatrains are devoted to introducing the jackal, which is the only animal character that appears on stage. Following this introduction, the jackal enters the scene holding a piece of meat in its mouth. Then he puts it down and performs a gesture that gives the impression of jumping into a river, and after that, he makes a rather comical call for help. This 
call for help is followed by two quatrains, one sung by the queen where she ridicules the jackal for his stupidity, and the other, sung by the jackal where he points out that her situation is no better. Then the jackal comes to the queen, urinates on her, and leaves the stage. The scene ends with two quatrains sung by a weeping queen who laments her situation while acknowledging that she herself is responsible for her plight.

Manamé Nātakaya indicates a significant leap from the Culladhanuggaha Jätaka in that it completely leaves out the mythical part of the story. It deals exclusively with activities in the terrestrial realm. In the play, the princess's ultimate realisation comes without any divine mediation. The state of abandonment in which she finds herself at the end of the play brings her the conviction that her current plight is the result of her own action. While the play presents a relatively detailed picture of the human world, it makes no direct reference to the divine realm within its narrative.

The differences between the Culladhanuggaha Jattaka and the two theatrical pieces based on that jätaka exemplify the distinction between the mythical consciousness and the poetic consciousness that Losev theorises. The disparity in the degrees of significance that the mythical component carries in the texts is what makes this distinction most evident. Theatre as a form of art operates within a framework that is fundamentally defined by poetic consciousness, and in the context of this consciousness, myth is invariably viewed from a point of view that is external to it. This external perspective recognises myth first and foremost as a "fantastic fabrication."19 Given this state of affairs, the explicitly mythical segment of the story in question is bound to be seen as a "fantastic fabrication" in the context of theatre. Considering the fundamental distinction that exists between the two types of consciousness, an attempt to restore the mythical dimension of the story, which the story presumably lost the moment it entered poetic consciousness, would appear to be counterproductive. The only productive way in which the story could function in the new realm is by adhering to the standards of that realm. In my view, the attempt on the part of the

\footnotetext{
19 The emphasis that Losev places on the need to view myth from the perspective of myth itself in the chapter "Myth is Neither an Invention Nor a Fiction Nor a Fantastic Fabrication" (7-8), which is the first chapter of his book, conveys the implication that myth always runs the risk of being perceived as a fantastic fabrication when approached from a perspective external to it.
} 
Manamé Kōlama and Manamé Nātakaya to minimize the mythical dimension of the source story is a reflection of the transformation that the story is obliged to undergo in order to maintain its validity in its new context.

The Manamé Kōlama employs certain theatrical techniques that help it minimize the mythical nature of the story, thereby establishing itself first and foremost as a theatrical play. The use of masks is one such technique. ${ }^{20}$ Every actor ${ }^{21}$ in the Manamé Kölama, as are those in the other segments of the broader performance that the Manamé Kōlama is part of, is masked. Although one could argue that the use of masks adds a certain mythical/mystical quality to the performance, the fact that the masks used in the Manamé Kölama are recognisably human looking (with the exception of the one worn by the actor playing the jackal, which is a depiction of the animal that it represents) emphasises the worldly nature of the characters. While these human and animal looking masks highlight the terrestrial nature of the reality that the spectator is witnessing, they also make the actors who are playing the characters impersonal, thereby reminding the spectator that what she is witnessing is essentially a theatrical reality. Another characteristic that reduces the mythical nature of the source story is the kind of language used in the Manamé Kōlama. In keeping with the linguistic tradition of kölam performances, ${ }^{22}$ the Manamé Kölama largely uses colloquial Sinhala, with the exception of a few verses in a form of literary Sinhala. The word 'hōtalaya'23 that appears in a line uttered by the subordinate to the Veddah king in the version of the Manamé Kölama under analysis ${ }^{24}$ injects a strong sense of contemporaneity into the story whose aura is fundamentally defined by antiquity. The jokes in the Manamé Kölama that evoke humour based on the duality of meanings of certain Sinhala words many of which have sexual connotations is a

\footnotetext{
20 The existing literature on kōlam dance recognizes the use of masks as a key defining characteristic of this dance tradition. For details, see Dela-Bandara; Nürnberger; Raghavan; Sarachchandra (Folk Drama of Ceylon); Wijesekera.

${ }^{21}$ In the kölam tradition, all the roles are performed by male actors.

${ }^{22}$ Focusing on the linguistic dimension of the kölam tradition, Nandadeva Wijesekera says, "The language [of kölam] is modern Sinhala ordinarily spoken by the people" (214).

${ }^{23}$ The Sinhala term hötalaya is based on the English term hotel and carries more or less the same meaning conveyed by the English term.

${ }^{24}$ Reporting on the royal couple to the Veddah king, the subordinate says, 'Éunāta Égollo sithāgena inne mé vanantharé api hōtalayak dāgena innawa kiyala' (Manamé Kölama, 38), which could be translated as, "But they think that we have opened a hotel in this forest."
} 
key characteristic of the linguistic dimension of the Kölama. The sense of contemporaneity, crudeness, and obscenity that defines the language of the Manamé Kōlama violates the sanctity of the myth that the source story contains, thereby distancing itself from the mythical dimension of the source story. The scene reinforces this violation where the jackal that, according to the source story, is a manifestation of the Lord Sakka urinates on the queen.

Like the Manamé Kōlama, Manamé Nātakaya also distances itself from the mythical dimension of its source story, but does so in a rather different manner. The most evident manner in which Manamé Nātakaya does it is by excluding the entire section of the story that is explicitly mythical. Since the play does not leave any space for a possible divine intervention, everything that happens in the play is seen as a result of human action. In this sense, the play could be seen as a celebration of humanity, and this clearly contrasts with the celebration of the divine that is seen in the Culladhanuggaha Jātaka. This reduction of the mythical dimension is reinforced by the detailed attention that the play pays to the activities that are associated with the terrestrial realm. The events that are in focus in the play are the marriage of the prince and the princess, the journey through the forest, the conflict and confrontation between the prince and the Veddah king, the death of the prince, and the conversation between the Veddah king and the princess. There is nothing mythical or supra-human about these activities. The shift from an emphasis on the concepts of divinity and spirituality to an emphasis on human virtue and romance that the transition from the Culladhanuggaha Jātaka to Manamé Nätakaya entails also reinforces the essentially worldly nature of the reality presented by the play.

The presentation style adopted by Manamé Nātakaya emphasises the theatricality of the activity presented, and such emphasis underscores poetic consciousness as the basic framework for understanding the presented reality. In terms of its presentation style, Manamé Nãtakaya falls into what Bharatamuni called the natyadharmi tradition of theatre, which means 'stylised' theatre. ${ }^{25}$ In the play, every utterance and every body movement is highly stylised. The literary form of Sinhala used in the play, which is markedly distinct from the colloquial Sinhala spoken by the spectator, adds to the linguistic stylisation conveyed by the mode of

25 The natyadharmi tradition contrasts with what Bharatamuni called the lokadharmi tradition, which refers to 'naturalistic' theatre. 
presentation. The body movements are stylised to such an extent that hardly any physical movement on stage takes place unaccompanied by music and/or singing. Another feature of the play that emphasises the theatricality of the reality that the play presents is its extensive use of South Assian classical music. Commenting on his use of music in his plays, Sarachchandra says, "I have been very conscious of the Indian theories of rasa and raga in my use of music. Ragas have set moods and I have employed those ragas proper to situations" (Gunawardena and Sarachchandra 200, emphasis in original). In light of the highly stylised and structured nature of Sarachchandra's use of music as implied by this comment, the significant use of South Asian classical music in Manamé Natakaya indicates that the ultimate goal of the play is artistic perfection. The reduction of the mythical dimension of the source story appears to be a necessary step towards achieving this goal.

Sarachchandra's claim that he was conscious of the Indian theory of rasa provides further insights into the status of the source story in the theatrical construct of Manamé Nätakaya. The rasa theory proposed by Bharatamuni defines different types of aesthetic tastes that art generates. While his original theory included eight types of rasa, a ninth type was added to the theory later. According to Susan L. Schwartz, "These rasas are described as consisting of precise performative postures, characteristic qualities of movement, facial expressions, and mudras or hand gestures" (15, emphasis in original). As Schwartz states, "Although the rasas may be understood as sentiments, they are never achieved by sentimentality. They may appear to result from emotion, but to be emotional is to lose any possibility of attaining the goal" (15-16). Sarachchandra argues:

The Indian theory [of rasa] says that aesthetic emotion is similar in some respects to the corresponding emotion in real life, but that behaviouristically it will be different. You enjoy it without exhibiting the symptoms or the overt behaviour associated with that state of feeling. It is a kind of inner enjoyment, a kind of passivity. (Gunawardena and Sarachchandra 198)

The idea of experiencing sentiments without being sentimental, experiencing emotions without being emotional, inner enjoyment, and inner passivity is parallel to Losev's notion of disinterested pleasure, which, according to him, defines the poetic consciousness. 
Given the importance that Sarachchandra's approach to theatre assigns to the generation of rasa or disinterested pleasure, Manamé Nätakaya, as a product of that tradition, clearly falls into the realm defined by the poetic consciousness. The play's association with the rasa theory also sheds light on the playwright's decision to emphasise the artistic dimension of the story over its mythical dimension.

Although the Manamé Kōlama and Manamé Nātakaya indicate a conscious departure from myth, certain factors that are both external and internal to the two theatrical pieces do not allow them to completely dissociate themselves from it. The cultural and religious significance of what defines the aura of the source story is one such external factor that does not allow them to dissociate themselves from the mythical dimension of the story. An assessment of the cultural and religious significance of the source story, which, in my view, plays a key role in determining how the story is appropriated in contexts other than its original context, should first and foremost take into consideration the story's status as a Buddhist jātaka story. Jātaka stories mainly present accounts of the Lord Buddha's former births. The belief that jätaka stories were told by the Buddha himself confers upon these stories a degree of religious significance similar to that attributed to the Buddhist doctrine itself. ${ }^{26}$ In this sense, the Culladhanuggaha Jätaka is primarily a sacred Buddhist text. Given the important role that popular Buddhism plays in defining the kind of consciousness in which the theatrical traditions represented by the Manamé Kōlama and Manamé Nätakaya are embedded and which is shared not only by the spectators but also by the creators of these theatrical pieces,a complete rejection of the mythical dimension of the story even in the context of art becomess problematic.

Another external factor that prevents the source story from completely leaving the realm of myth when it is transferred from the jātaka story to the stage is the fundamentally mythical nature of theatre as an art form in the South Asian artistic consciousness. According to Bharatamuni's Nā la $y a$ Śāstra, which provides the theoretical context for many of the South Asian theatrical traditions including those in Sri Lanka, theatre was invented by Brahma, the

\footnotetext{
${ }^{26}$ Alexandra R. Kapur-Fic argues, "These stories continue to be held in the highest reverence "by the Buddhists everywhere because it is believed that the Buddha himself told these stories to his disciples during his lifetime as part of his sermons and to impart specific lessons in moral and ethical values" (15-16).
} 
god of creation (Bharatamuni 1-2). According to this origin myth, Brahma composes a treatise on theatre, which he then passes on to Bharata who is introduced to Brahma by Śakra/Sakka as a sage "conversant with the esoteric mystery of the Vedas and perfect in the observance of holy vows" and also "capable of receiving, retaining and putting it into practical use" (Bharatamuni 2-3). From the perspective of this myth, theatre itself is a product of divine intervention in the human world. By virtue of the fact that the kōlam tradition and the nädagam tradition, which provide the context for the Manamé Kōlama and Manamé Nātakaya respectively, are part of traditional South Asian theatre, which is largely defined by Bharatamuni's conception of theatre, they both could be seen as directly or indirectly subscribing to Bharatamuni's mythical perspective on theatre. In a context where the theatre space is conceptualised as a mythical space and the story performed is explicitly mythical, a complete rejection of the mythical dimension of the story would not only deprive the story of its 'life' but also violate the widely perceived sanctity of the traditional theatre space.

Despite their conscious departure from the myth in the source story, both the Manamé Kōlama and Manamé Nātakaya embody certain features that keep them tied to the idea of myth. In the case of the Manamé Kólama, most of these features are to be found in the broader performance which the Manamé Kölama is part of. At the beginning of a kōlam performance, the moderator/presenter who plays the role of introducing the characters to the stage recites verses that pay homage to Brahma and the other Hindu deities multiple times, invoke blessings on the spectators, request the gods to protect the spectators and bless them with long healthy lives, worship the Buddha, his doctrine, and the Buddhist order, and request certain deities to grace the occasion with their presence (Dela-Bandara 93-97). While the verses addressed to Brahma and the Hindu gods are either in Sanskrit or in a form of Sinhala heavily influenced by Sanskrit, those addressed to the Buddha, his doctrine, and the Buddhist order are in literary Sinhala. The next segment of the kölam performance consists of a set of verses that present the origin myth of kōlam as an art form, which is essentially a story of a divine intervention. ${ }^{27}$ Many of the masked dancers who appear on

${ }^{27}$ Nürnberger summarises the origin myth in the following manner, "In the literature on this subject, the story of its origin is narrated in different versions, but the essence remains always the same: a queen, in most versions the consort of the mythical first king Mahasammata, is with child and is afflicted with longings due to 
stage in the second part of the performance represent various kinds of divine/mythical beings. The conclusion of the kōlam performance is marked by the appearance of the mythical being called Garā Yakā, which is "a component part of many exorcistic rituals" (Nürnberger 114). Given that the objective of the Garā Yakā performance in ritualistic contexts has been to ward off evil spirits (Dela-Bandara 250), the appearance of the Garā Yakā in the concluding segment of the kōlam performance undoubtedly attributes to the performance ritual significance.

In the case of Manamé Nātakaya, a couple of features that attribute the text a similar mythical significance could be found at the beginning and the end of the play. The play begins with a verse presented by the moderator/presenter/leader of the chorus in which he praises and worships the Buddha. This introductory verse is followed by another verse, which presents an abridged version of the story of the play. The fourth line of this verse states that the play is an attempt to act out the story in keeping with the standards of traditional theatre. Following this introduction to the play, the chorus sings three short verses in which it seeks permission first from the gods of the sun and the moon who are in charge of the celestial realm, second from the god of the earth who is in charge of the terrestrial realm, and third from the rest of the gods for the play to take place. At the end of the play, all the characters come on the stage and collectively sing a song, which invokes the blessings of the Triple Gem of Buddhism (the Buddha, his doctrine, and the Buddhist order) and the entire pantheon of gods (mainly of the Buddhist tradition).

These features of the Manamé Kōlama and Manamé Nātakaya that are explicitly mythical in nature indicate an attempt to reinforce the mythical dimension of the source story weakened by the demands of the poetic consciousness that governs the new contexts of the story. Although the transition from the realm of myth to the realm of art has resulted in the source story losing much of its mythical character, the fact that the story is still couched in a broader context significantly defined by myth strengthens the mythical nature of the story. In this sense, the source story has not completely left the mythical realm and comfortably located itself in the artistic realm dominated by what Losev recognises as the poetic consciousness.

pregnancy (dola dukkha). She craves, however, not for food but for a maskeddrama. The masks are now provided by the gods. Finally it was possible to satisfy the cravings of the queen. Thus this suggests an origin in a fertility ritual" (115). 


\section{Conclusion}

The simultaneous processes of the de-mythicisation and remythicisation in the context of the Manamé Kōlama and Manamé Nätakaya convert the two theatrical pieces into realities that can best be categorised under what Vladimir Marchenkov calls mythosophy, which, according to him, is "a hybrid form" that "neither reproduces traditional myth nor completely dissolves the latter in rationalistic allegorizing" (xvii). The hybrid form that mythosophy represents is a space defined by an interaction between myth and art as a philosophical tradition. Mythosophy therefore recognises the validity and significance of both myth and art. Given the importance that mythosophy attributes to both myth and art, a conceptualisation of the two theatrical pieces in question as mythosophy would invariably recognise those theatrical pieces as embodying a broader consciousness defined by both the mythical consciousness and the poetic consciousness. In such a context, any serious attempt to understand these theatrical pieces should employ an approach that recognises and accounts for this broader consciousness.

\section{References}

Bharatamuni. The Nā⿴囗ya Śāstra of Bharatamuni. $2^{\text {nd }}$ rev. ed. Delhi: Sri Satguru Publications, 2000. Print.

Brecht, Bertolt. Brecht on Theatre: The Development of an Aesthetic. Trans. John Willett. New York: Hill and Wang, 1992. Print.

Cassirer, Ernst.The Philosophy of Symbolic Forms: Volume Two: Mythical Thought. Trans. Ralph Manheim. New Haven: Yale University Press, 1955. Print.

Culladhanuggaha Jātaka in Pansiya Panas Jātaka Poth Wahanse. Colombo: S. Godagé and Brothers, 2012: 833-834. Print.

Dela-Bandara, Gamini. Sinhala Kōlam Sampradaya [The Sinhala Kōlam Tradition]. Kelaniya: Sambhavya Prakashana, 2000. Print.

Gunawardena, A. J., and Ediriweera R. Sarachchandra. "An Interview with E. R. Sarachchandra." The Drama Review: TDR 15.2 (1971): 193-200. Web. 1 Sep. 2013.

Kant, Immanuel. Critique of the Power of Judgement. Ed. Paul Guyer. Trans. Paul Guyer and Eric Matthews. New York: Cambridge University Press, 2000. Print.

Kapur-Fic, Alexandra R. The Jatakas: Times and Lives of Bodhisattva. New Delhi: Abhivav Publications, 2010. Print. 
Losev, Aleksei Fyodorovich. Dialectics of Myth. Trans. Vladimir Marchenkov. London: Routledge, 2003. Print.

Manamé Kōlama [The Manamé Kōlama]. Ed. Tissa Kariyawasam. Kelaniya: Sheela Printing Works, 1986. Print.

Marchenkov, Vladimir. The Orpheus Myth and the Powers of Music. Hillsdale, NY: Pendragon Press, 2009. Print.

Nürnberger, Marianne. Dance is the Language of the Gods: Chitrasena School and the Traditional Roots of Sri Lankan Stage-Dance. Amsterdam: VU University Press: 1998. Print.

Raghavan, M. D. Si]hala Nälum: Dances of the Sinhalese. Colombo:

M. D. Gunasena \& Co., Ltd., 1967. Print.

Sarachchandra, Ediriweera. Manamé Nātakaya. Colombo: S. Godagé and Brothers, 1958. Print.

--.. The Folk Drama of Ceylon. $2^{\text {nd }}$ ed. Colombo: Department of Cultural Affairs, 1966. Print.

Schwartz, Susan L. Rasa: Performing the Divine in India. New York: Columbia University Press, 2004. Print.

Wijesekera, Nandadeva. Deities and Demons, Magic and Masks: Part II. Colombo: M. D. Gunasena \& Co., Ltd., 1989. Print.

Wijesooriya, Sarath. Ediriweera Sarachchandrayangé Nā⿴囗十ya Dhrustiya [The Theatrical Perspective of Ediriweera Sarachchandra]. Colombo: S. Godagé and Brothers, 1997. Print. 